\title{
Seed Characteristics Diversity in Sponge Gourd (Luffa aegyptiaca Mill.) Germplasms from Hatay Region in Turkey
}

\author{
Kazım MAVİ ${ }^{1 *}$ Kazim GÜNDÜZ², Dilek YILDIRIM ${ }^{1}$, Fulya UZUNOĞLU ${ }^{1}$ \\ ${ }^{1}$ Department of Horticulture, Faculty of Agriculture, University of Mustafa Kemal, Antakya, Turkey \\ ${ }^{2}$ Department of Horticulture, Faculty of Agriculture, University of İnönü, Battalgazi, Malatya, Turkey \\ *corresponding author: kazimmavi@mku.edu.tr
}

Bulletin UASVM Horticulture 75(1) / 2018

Print ISSN 1843-5262, Electronic ISSN 1843-536X

DOI:10.15835/buasvmcn-hort: 000118

\begin{abstract}
The objective of this study was to evaluate seed characteristics of sponge gourd, to establish a core collection of sponge gourd with the germplasm collected throughout the Hatay region. A mini-core collection was assessed for morphological performance and some seed traits. Substantial variations of seed characteristics: seed length, seed width, seed thickness (mm), seed index (length/width), seed size (length $\times$ width, $\mathrm{mm}^{2}$ ), seed colour, seedcoat surface, seed shape, seed wing, and 100 -seed weight were investigated. Seed length, width and thickness were varied as $15.12-8.97 \mathrm{~mm}, 9.71-6.25 \mathrm{~mm}$ and $2.86-2.16 \mathrm{~mm}$ respectively. The seed sizes were determined from small (31 DÖ 06) to big (31 DE 04). Seed colours were ranged from black to white, even a brown colour like $07 \mathrm{MA}$

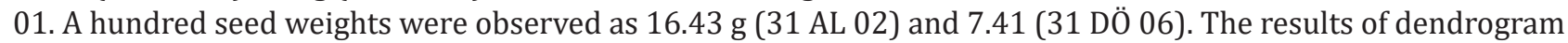
indicated that seed traits of the sponge gourd genotypes were separating in five groups. This collection of sponge gourds will be useful for the gene pools and a wide range of phenotypic variations to provide a good source of diversity for developing of sponge gourd cultivars in breeding programs.
\end{abstract}

Keywords: Luffa cylindrica, Luffa acutangula, seed traits, principal component analysis

\section{Introduction}

Vegetable crops, especially the cucurbits (gourds, melons, squashes and pumpkins), are rich sources of nutrients. Sponge gourd is one of the less known in Cucurbits. However, sponge gourd is a popular vegetable in the tropics and is essentially an old-world species. Immature fruits of sponge gourd are used as vegetables and mature fruits as fibres. It is cultivated in Asia and Africa, and widely used as a vegetable in India, China and other Asian countries.

The genus Luffa consists of ten species: Luffa aegyptiaca Mill., Luffa acutangula Roxb., Luffa graveolens Roxb., Luffa echinata Roxb.,
Luffa umbellata M. Roem., Luffa tuberosa Roxb., Luffa quinquefida (Hook. \& Arn.) Seem., Luffa astorii Svens. Luffa saccata F.Muell. ex I. Telford. and Luffa hermofrodita Singh \& Bhandari. Luffa aegyptiaca Mill. and Luffa acutangula Roxb. are economically cultivated species in the world. Luffa hermaphrodita is also cultivated species in minor areas of India (Marr et al., 2005).

Plant genetic resources and germplasms are fundamental sources for plant breeding that the assessment of the genetic diversity among genotypes is useful to facilitate more efficient use of plant genetic resources. Hatay has a rich genetic 
Table 1. Some details of sponge gourd genotypes used in this study

\begin{tabular}{|c|c|c|c|c|}
\hline No. & Genotype code & Species & Area of collection & Type of cultivation \\
\hline 1 & 31 AR 01 & Luffa aegyptiaca & Arsuz & Ornamental \\
\hline 2 & 31 AR 02 & Luffa aegyptiaca & Arsuz & Ornamental \\
\hline 3 & 31 AR 03 & Luffa aegyptiaca & Arsuz & Ornamental \\
\hline 4 & 31 AR 04 & Luffa aegyptiaca & Arsuz & Ornamental \\
\hline 5 & 31 AR 05 & Luffa aegyptiaca & Arsuz & Ornamental \\
\hline 6 & 31 DE 01 & Luffa aegyptiaca & Defne & Fibres \\
\hline 7 & 31 DE 02 & Luffa aegyptiaca & Defne & Fibres \\
\hline 8 & 31 DE 03 & Luffa aegyptiaca & Defne & Fibres \\
\hline 9 & 31 DE 04 & Luffa aegyptiaca & Defne & Fibres \\
\hline 10 & 31 DE 05 & Luffa aegyptiaca & Defne & Fibres \\
\hline 11 & 31 DE 06 & Luffa aegyptiaca & Defne & Fibres \\
\hline 12 & 31 DE 07 & Luffa aegyptiaca & Defne & Fibres \\
\hline 13 & 31 SA 01 & Luffa aegyptiaca & Samandağ & Ornamental \\
\hline 14 & 31 AN 01 & Luffa aegyptiaca & Antakya & Ornamental \\
\hline 15 & 31 AN 02 & Luffa aegyptiaca & Antakya & Ornamental \\
\hline 16 & 31 AN 03 & Luffa aegyptiaca & Antakya & Ornamental \\
\hline 17 & 31 AN 04 & Luffa aegyptiaca & Antakya & Ornamental \\
\hline 18 & 31 AN 05 & Luffa aegyptiaca & Antakya & Ornamental \\
\hline 19 & 31 DÖ 01 & Luffa aegyptiaca & Dörtyol & Ornamental \\
\hline 20 & 31 DÖ 02 & Luffa aegyptiaca & Dörtyol & Ornamental \\
\hline 21 & 31 Dö 03 & Luffa aegyptiaca & Dörtyol & Ornamental \\
\hline 22 & 31 DÖ 04 & Luffa aegyptiaca & Dörtyol & Ornamental \\
\hline 23 & 31 DÖ 05 & Luffa aegyptiaca & Dörtyol & Ornamental \\
\hline 24 & 31 DÖ 06 & Luffa aegyptiaca & Dörtyol & Ornamental \\
\hline 25 & 31 YA 01 & Luffa aegyptiaca & Yayladağı & Ornamental \\
\hline 26 & 31 YA 02 & Luffa aegyptiaca & Yayladağ & Ornamental \\
\hline 27 & 31 YA 03 & Luffa aegyptiaca & Yayladağ & Ornamental \\
\hline 28 & 31 YA 04 & Luffa aegyptiaca & Yayladağ & Ornamental \\
\hline 29 & 31 AL 01 & Luffa aegyptiaca & Altınözü & Ornamental \\
\hline 30 & 31 AL 02 & Luffa aegyptiaca & Altınözü & Ornamental \\
\hline 31 & 31 AL 03 & Luffa aegyptiaca & Altınözü & Ornamental \\
\hline 32 & 31 AL 04 & Luffa aegyptiaca & Altınözü & Ornamental \\
\hline 33 & 31 PA 01 & Luffa aegyptiaca & Payas & Ornamental \\
\hline 34 & 31 ER 01 & Luffa aegyptiaca & Erzin & Ornamental \\
\hline 35 & 01 AD 01 & Luffa aegyptiaca & Adana & Ornamental \\
\hline 36 & 07 MA 01 & Luffa aegyptiaca & Antalya & Ornamental \\
\hline 37 & South Korea & Luffa aegyptiaca & Control & Vegetable \\
\hline 38 & China & Luffa acutangula & Control & Vegeteble \\
\hline
\end{tabular}

variability in terms of fruit size and shape and is one of the centres of diversity in Turkey for sponge gourds. Mature fruits of sponge gourd are used fibres for hygienic washer in Hatay. However, no data was found about variability for various traits in germplasm in Turkey. A mini-core collection of sponge gourd germplasm from diverse geographic regions of Hatay was assessed for morphological performance and some seed traits. These genotypes could play a significant role in future breeding programs (Mavi and Gündüz, 2016). In particular, we sought to characterize agronomic, morphological and quality characteristics of the sponge gourd genotypes and to provide information about diversity in sponge gourd genotypes present for international breeders interested in Turkish sponge gourd genetic resources. The objective of this study was to evaluate the seed characteristics of sponge gourd, to establish a sponge gourd core-collection with the germplasms collected throughout the Hatay region.

\section{Material and methods}

A total number of 38 (Collected 36 genotypes from Turkey, and two genotypes from China and South Korea) genotypes were used in this experiment. The seeds of the thirty-six genotypes 


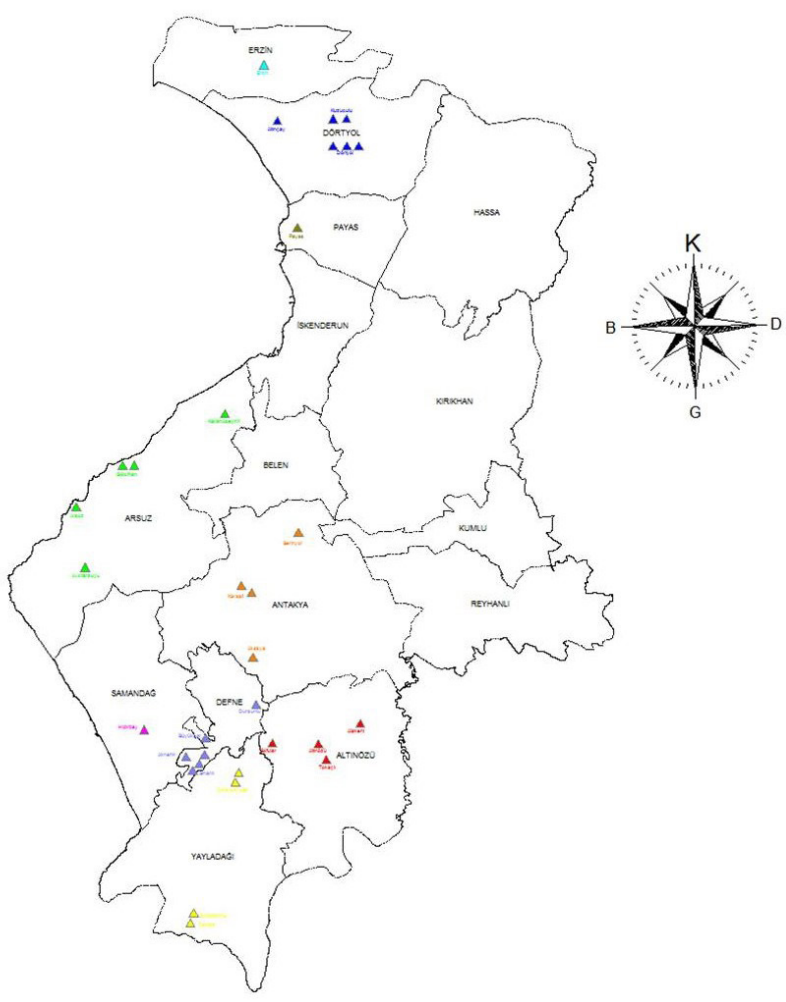

Figure 1. Location of collected genotypes in Hatay province.

were collected from several areas of Hatay province of Turkey. Sources and genotypes were presented in Table 1 and Figure 1.

The variabilities of seed morphological traits [Seed length $(\mathrm{mm})$, seed width $(\mathrm{mm})$, seed thickness $(\mathrm{mm})$, seed index (length/width), seed size (length $\times$ width, $\mathrm{mm}^{2}$ ), seed colour, seed coat surface, seed shape, seed wing and 100 seed weight (g)] were determined in collected genotypes. The morphological study of the seeds was carried out on a sample of 20 seeds per accession and repetition. Seed morphological traits determined according to Heiser and Schilling (1988), and Heneidak and Khalik (2015).

Mean data for each characters were evaluated by one-way analysis of variance (ANOVA) followed by Duncan's multiple range test when the $P$ value less than 0.05 was considered significant. Principal component (PC) and cluster analysis were carried out using the PRINCOMP procedure and UPGMA method (Unweighted Pair-group Method, Arithmetic Average) respectively. Data processing was performed using the NTSYS (Numerical Taxonomy System) program.

\section{Results and discussions}

The seed morphological characters for studied genotypes of the genus Luffa are summarized in Table 2 and 3. The morphological characters of seeds showed wide variation. The range of variation for seed weight, width and length was very large. While the seed width was ranged from $9.71 \mathrm{~mm}$ (31 DE 03) to $6.25 \mathrm{~mm}$ (31 DÖ 06), the seed length was changed from $15.12 \mathrm{~mm}$ (31 DE 04) to 8.97 $\mathrm{mm}$ (31 DÖ 06). The highest seeds thickness (2.86 $\mathrm{mm}$ ) was measured in 31 DÖ 01, but the smallest thickness $(2.16 \mathrm{~mm})$ was measured in 31 Dö 03. Similarly, seed size and seed index were varied among the selected genotypes of Luffa.

The seed weight was ranged from $7.3 \mathrm{~g}$ (31 DÖ 06) to $16.4 \mathrm{~g}$ (31 AL 02). Other genotypes were determined between these values. Seed colour of genotypes varied from black to white. The seed surface ranged from smooth to scaly. While of genotypes have a smooth surface, some of them (31 DE 02, 31 DÖ 02 and China) have a wrinkled, creased and scaly. Seed shape in the genotypes categorized by ovoid, elongate ovoid and elongate. 31 DÖ 03 has a very conspicuous seed wing, but the genotype of China ( $L$. acutangula) lack of the seed wing (Table 3 and Figure 2). 
Table 2. Some seed morphological characters at genotypes of $L u f f a$

\begin{tabular}{|c|c|c|c|c|c|}
\hline $\begin{array}{l}\text { Genotype } \\
\text { code }\end{array}$ & $\begin{array}{l}\text { Seed length } \\
(\mathrm{mm})\end{array}$ & $\begin{array}{l}\text { Seed width } \\
(\mathrm{mm})\end{array}$ & $\begin{array}{c}\text { Seed thickness } \\
(\mathrm{mm})\end{array}$ & $\begin{array}{c}\text { Seed size } \\
\left(\mathrm{mm}^{2}\right)\end{array}$ & $\begin{array}{c}\text { Seed index } \\
\text { L/W }\end{array}$ \\
\hline 31 AR 01 & $13.57 \mathrm{de}$ & 8.40 fghij & $2.49 \operatorname{lm} n o$ & 114 & 1.62 \\
\hline 31 AR 02 & $11.85 \mathrm{stu}$ & 8.36 fghij & 2.54 hijklm & 99 & 1.42 \\
\hline 31 AR 03 & 12.35 mnop & $8.93 \mathrm{c}$ & 2.71 cdef & 110 & 1.38 \\
\hline 31 AR 04 & $11.45 \mathrm{v}$ & $7.75 \mathrm{mno}$ & 2.68 defg & 89 & 1.48 \\
\hline 31 AR 05 & $12.42 \mathrm{mno}$ & $7.75 \mathrm{mno}$ & $2.70 \mathrm{cdef}$ & 96 & 1.60 \\
\hline 31 DE 01 & 11.98 prst & $7.85 \mathrm{lmn}$ & 2.61 efghij & 94 & 1.53 \\
\hline 31 DE 02 & 11.92 rst & 8.39 fghij & $2.70 \mathrm{cdef}$ & 100 & 1.42 \\
\hline 31 DE 03 & $13.94 \mathrm{c}$ & $9.71 \mathrm{a}$ & 2.48 lmno & 135 & 1.44 \\
\hline 31 DE 04 & $15.12 \mathrm{a}$ & $9.47 \mathrm{ab}$ & $2.31 \mathrm{rs}$ & 143 & 1.60 \\
\hline 31 DE 05 & $11.86 \mathrm{stu}$ & 7.74 no & $2.68 \mathrm{defg}$ & 92 & 1.53 \\
\hline 31 DE 06 & $11.49 \mathrm{uv}$ & $7.93 \mathrm{klmn}$ & 2.40 oprs & 91 & 1.45 \\
\hline 31 DE 07 & $12.70 \mathrm{ijklm}$ & $8.81 \mathrm{~cd}$ & $2.29 \mathrm{~s}$ & 112 & 1.44 \\
\hline 31 SA 01 & $13.45 \mathrm{def}$ & 8.55 defg & $2.73 \mathrm{bcd}$ & 115 & 1.57 \\
\hline 31 AN 01 & $13.15 \mathrm{fgh}$ & $8.65 \mathrm{cdef}$ & $2.51 \mathrm{jklmn}$ & 114 & 1.52 \\
\hline 31 AN 02 & $12.52 \mathrm{lmn}$ & 8.53 defgh & $2.48 \mathrm{lmno}$ & 107 & 1.47 \\
\hline 31 AN 03 & 11.80 stuv & 7.61 no & $2.75 \mathrm{bcd}$ & 90 & 1.55 \\
\hline 31 AN 04 & 13.40 defg & $8.70 \mathrm{cdef}$ & $2.50 \mathrm{klmno}$ & 117 & 1.54 \\
\hline 31 AN 05 & $12.48 \mathrm{mn}$ & 8.42 fghi & $2.34 \mathrm{rs}$ & 105 & 1.48 \\
\hline 31 DÖ 01 & $13.21 \mathrm{efgh}$ & 7.47 op & $2.86 \mathrm{a}$ & 99 & 1.77 \\
\hline 31 DÖ 02 & $13.49 \mathrm{def}$ & $9.57 \mathrm{a}$ & $2.82 \mathrm{ab}$ & 129 & 1.41 \\
\hline 31 DÖ 03 & $13.59 \mathrm{~d}$ & $8.78 \mathrm{cde}$ & $2.16 \mathrm{t}$ & 119 & 1.55 \\
\hline 31 DÖ 04 & 13.22 defgh & $8.65 \mathrm{cdef}$ & $2.80 \mathrm{abc}$ & 114 & 1.53 \\
\hline 31 DÖ 05 & $12.94 \mathrm{hij}$ & 8.28 ghij & $2.73 \mathrm{bcd}$ & 107 & 1.56 \\
\hline 31 DÖ 06 & $8.97 \mathrm{y}$ & $6.25 \mathrm{r}$ & 2.53 hijklm & 56 & 1.44 \\
\hline 31 YA 01 & 12.02 prst & $7.89 \mathrm{klmn}$ & 2.46 mnopr & 94 & 1.52 \\
\hline 31 YA 02 & 12.06 oprs & 8.49 defgh & 2.62 efghi & 102 & 1.42 \\
\hline 31 YA 03 & $11.90 \mathrm{rst}$ & $7.83 \mathrm{lmn}$ & 2.42 noprs & 93 & 1.52 \\
\hline 31 YA 04 & 11.79 stuv & $7.93 \mathrm{klmn}$ & $2.31 \mathrm{rs}$ & 94 & 1.49 \\
\hline 31 AL 01 & 12.87 hijkl & $8.10 \mathrm{ijkl}$ & 2.64 defgh & 104 & 1.59 \\
\hline 31 AL 02 & $14.32 \mathrm{~b}$ & 8.47 efgh & 2.61 efghij & 121 & 1.69 \\
\hline 31 AL 03 & 12.90 hijk & 8.20 hijk & 2.58 ghijkl & 106 & 1.57 \\
\hline 31 AL 04 & $12.53 \mathrm{klmn}$ & 7.65 no & 2.42 noprs & 96 & 1.64 \\
\hline 31 PA 01 & 11.98 prst & 7.68 no & 2.35 prs & 92 & 1.56 \\
\hline 31 ER 01 & 12.26 nopr & 8.59 defg & 2.72 bcde & 105 & 1.43 \\
\hline 01 AD 01 & 13.05 ghi & $9.27 \mathrm{~b}$ & $2.52 \mathrm{ijklmn}$ & 121 & 1.41 \\
\hline 07 MA 01 & 12.27 nopr & $8.08 \mathrm{jklm}$ & 2.37 oprs & 99 & 1.52 \\
\hline South Korea & 11.65 tuv & $7.21 \mathrm{p}$ & $2.82 \mathrm{ab}$ & 84 & 1.62 \\
\hline China & $12.63 \mathrm{jklmn}$ & $7.77 \mathrm{lmno}$ & 2.47 lmnop & 98 & 1.63 \\
\hline
\end{tabular}

The seeds of the genotypes of Luffa under investigation varied in size, shape and colour. Prakash et al. (2014) determined the genotypes of the L. aegyptiaca group, variability in 100 -seed weight (6.58-18.58 g), length (10.0-14.0 mm), and width (5.6-9.8 mm). Our results about 100 seed weight, seed length and width are similar to the result of Prakash et al. (2014). Heneidak and Khalik (2015) presented seed colour varied from black in Luffa acutangula and black to brown in L. aegyptiaca. But it can be white colour. Present study showed white coloured genotypes (Figure 2).
The result of principle component analysis showed that there was variation among the genotypes depending on the seed morphological characters. The first four PCs gave Eigen values greater than 1.0 and explained $83.7 \%$ of the total variation, with $38.1,21.6,14.0$ and $10.0 \%$, respectively. We considered as values above 0.47 to be significant for important parameters. The important variables composed in PC1 were: SL, SW, SS, SWe, and Su. While SW, SI and SSh were the most important variables in PC2, ST, SC, Su and Swi were the most important variables for PC3 (Table 4). 
Table 3. Some seed morphological characters at genotypes of Luffa

\begin{tabular}{|c|c|c|c|c|c|}
\hline $\begin{array}{l}\text { Genotype } \\
\text { code }\end{array}$ & $\begin{array}{c}\text { Seed weight } \\
\text { (g) }\end{array}$ & Seed color & Surface & Seed shape & $\begin{array}{l}\text { Seed } \\
\text { wing }\end{array}$ \\
\hline 31 AR 01 & $15.0 \mathrm{bc}$ & Black & Smooth & Elongate ovoid & Indistinct \\
\hline 31 AR 02 & $12.3 \mathrm{kl}$ & Black & Smooth & Ovoid & Present \\
\hline 31 AR 03 & $13.4 \mathrm{gh}$ & Black & Smooth & Ovoid & Present \\
\hline 31 AR 04 & $9.5 \mathrm{~s}$ & Black & Smooth & Ovoid & Present \\
\hline 31 AR 05 & $13.2 \mathrm{ghi}$ & Black & Smooth & Elongate ovoid & Present \\
\hline 31 DE 01 & $11.6 \mathrm{n}$ & Black & Smooth & Ovoid & Present \\
\hline 31 DE 02 & $10.8 \mathrm{p}$ & Black & Smooth & Ovoid & Indistinct \\
\hline 31 DE 03 & $15.1 \mathrm{bc}$ & Black & Wrinkled & Ovoid & Present \\
\hline 31 DE 04 & $14.5 \mathrm{~cd}$ & Brown & Wrinkled & Elongate ovoid & Indistinct \\
\hline 31 DE 05 & $10.4 \mathrm{pr}$ & Black & Smooth & Ovoid & Present \\
\hline 31 DE 06 & $10.1 \mathrm{r}$ & Black & Smooth & Ovoid & Indistinct \\
\hline 31 DE 07 & $11.7 \mathrm{mn}$ & Black & Smooth & Ovoid & Present \\
\hline 31 SA 01 & $14.7 \mathrm{bc}$ & Black & Smooth & Elongate ovoid & Present \\
\hline 31 AN 01 & $13.9 \mathrm{ef}$ & Black & Wrinkled & Ovoid & Present \\
\hline 31 AN 02 & $11.6 \mathrm{n}$ & Black & Smooth & Ovoid & Present \\
\hline 31 AN 03 & $8.4 \mathrm{k}$ & Black & Smooth & Elongate ovoid & Present \\
\hline 31 AN 04 & $14.3 \mathrm{de}$ & Black & Smooth & Ovoid & Present \\
\hline 31 AN 05 & $12.7 \mathrm{ijk}$ & Black & Smooth & Ovoid & Indistinct \\
\hline 31 Dö 01 & $13.9 \mathrm{ef}$ & Black & Smooth & Elongate & Indistinct \\
\hline 31 Dö 02 & $15.4 \mathrm{~b}$ & White & Creased & Ovoid & Present \\
\hline 31 Dö 03 & $12.5 \mathrm{jkl}$ & Black & Smooth & Elongate ovoid & Present \\
\hline 31 Dö 04 & $15.7 \mathrm{ab}$ & Black & Smooth & Ovoid & Present \\
\hline 31 Dö 05 & $14.7 \mathrm{bcd}$ & Black & Smooth & Elongate ovoid & Present \\
\hline 31 Dö 06 & $7.3 \mathrm{u}$ & Black & Smooth & Ovoid & Present \\
\hline 31 YA 01 & $10.6 \mathrm{pr}$ & Black & Smooth & Ovoid & Present \\
\hline 31 YA 02 & $13.5 \mathrm{fg}$ & Gray & Smooth & Ovoid & Present \\
\hline 31 YA 03 & 11.4 no & Black & Smooth & Ovoid & Present \\
\hline 31 YA 04 & $10.5 \mathrm{pr}$ & Black & Smooth & Ovoid & Present \\
\hline 31 AL 01 & $11.7 \mathrm{mn}$ & Black & Smooth & Elongate ovoid & Present \\
\hline 31 AL 02 & $16.4 \mathrm{a}$ & Black & Smooth & Elongate & Present \\
\hline 31 AL 03 & $12.1 \mathrm{~lm}$ & Black & Wrinkled & Elongate ovoid & Present \\
\hline 31 AL 04 & $12.5 \mathrm{jkl}$ & White & Smooth & Elongate ovoid & Present \\
\hline 31 PA 01 & $9.4 \mathrm{~s}$ & Black & Smooth & Elongate ovoid & Present \\
\hline 31 ER 01 & $12.9 \mathrm{hij}$ & Black & Smooth & Ovoid & Present \\
\hline 01 AD 01 & $14.7 \mathrm{bcd}$ & Black & Smooth & Ovoid & Present \\
\hline 07 MA 01 & 10.9 ор & Brown & Smooth & Ovoid & Present \\
\hline South Korea & $9.4 \mathrm{~s}$ & Black & Smooth & Elongate ovoid & Present \\
\hline China & $15.0 \mathrm{bc}$ & Dark Black & Scaly & Elongate ovoid & Absent \\
\hline
\end{tabular}

The UPGMA dendrogram obtained with 10 seed morphological traits for the 38 sponge gourd genotypes, were given in Figure 1. The accessions were clustered into five main groups. Group 1 consisted of 23 accessions showed very similar seed characters. The genotype of South Korea and 31DÖ06 were classified alone in group III and group V.

Similar results were reported in genotypes of Luffa hermaphrodita (Choudhary et al., 2009), Luffa acutangula (Heiser and Schilling 1988; Marr et al., 2005; Choudhary et al,. 2011), Luffa aegyptiaca (Heiser and Schilling 1988; Marr et al., 2005), used morphological markers like a seed weight, seed length, seed width, seed colour for assessment of relationships and estimating genetic diversity.

\section{Conclusions}

Characterization and conservation of crop genetic resources are major components in breeding improvement programs, especially with unattended and minor vegetable crops. The present study showed the existence of considerable genetic variability amongst Turkey sponge gourd genotypes. The availability of sponge 


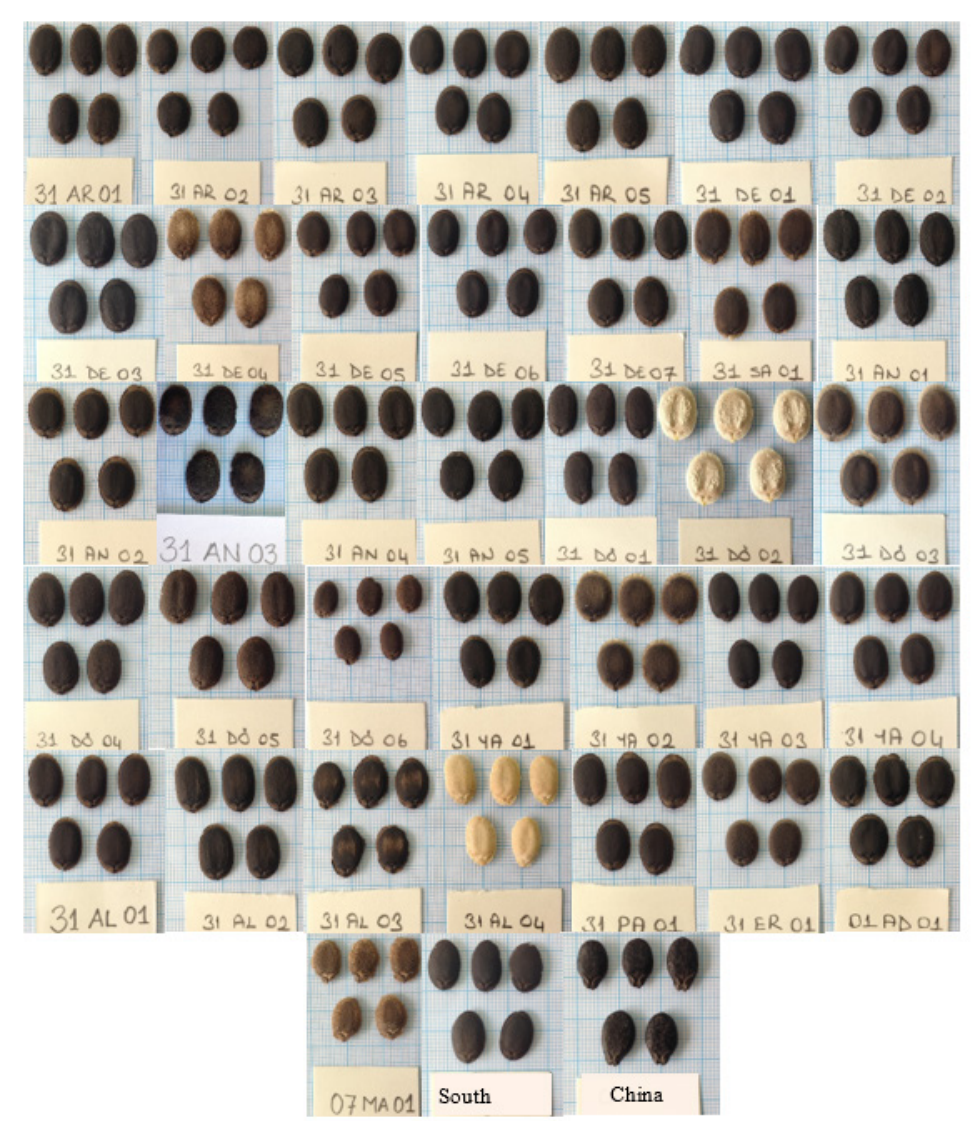

Figure 2. Variation for seed morphology among 36 sponge gourd landrace collections from Hatay province of Turkey and two control genotypes in South Korea and China (Luffa acutangula). Seeds of different genotypes are not represented at the same scale; the size of the grid cells is $1 \times 1 \mathrm{~cm}$.

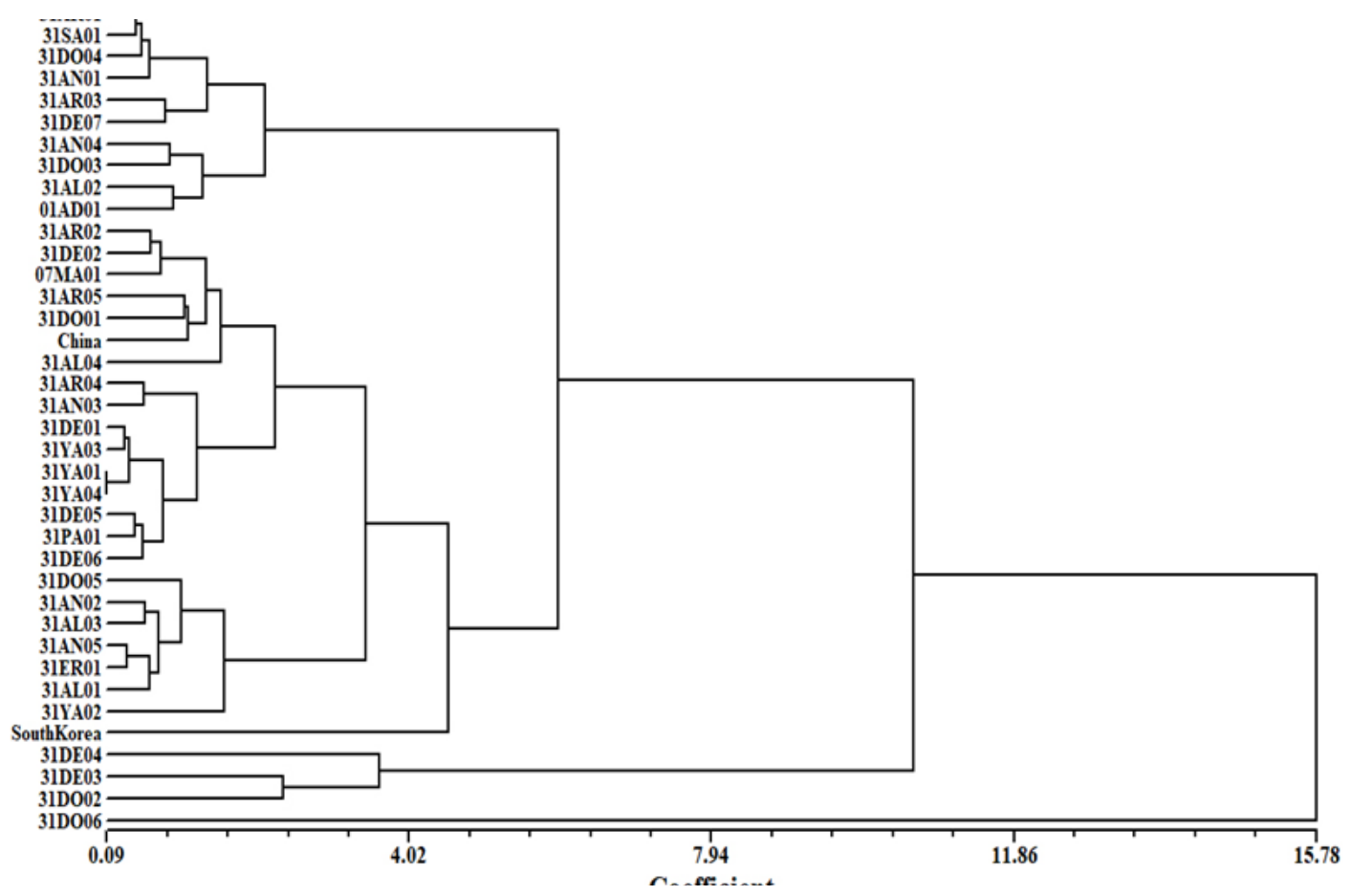

Figure 3. UPGMA dendrogram based on seed morphological characters distances 36 sponge gourd landrace collections from the Hatay province of Turkey and two control genotypes in South Korea and China (Luffa acutangula). 
Table 4. Eigen values and cumulative variance of the first four-principle component (PC) analysis for some seed morphological characters at genotypes of Luffa

\begin{tabular}{ccccc}
\hline Principal component & PC1 & PC2 & PC3 & PC4 \\
\hline Eigen value & 3.8 & 2.2 & 1.4 & 1.0 \\
\hline Variance (\%) & 38.1 & 21.6 & 14.0 & 10.0 \\
\hline Cumulative variance (\%) & 38.1 & 59.7 & 73.7 & 83.7 \\
\hline & & & & \\
\hline Characters & & & & \\
\hline Seed length (SL, mm) & $\mathbf{0 . 4 8}$ & -0.15 & -0.14 & -0.02 \\
\hline Seed width (SW, mm) & 0.44 & 0.29 & -0.17 & 0.11 \\
\hline Seed thickness (ST, mm) & -0.02 & -0.17 & 0.30 & $\mathbf{0 . 8 1}$ \\
\hline Seed size (SS, $\mathrm{mm}^{2}$ ) & $\mathbf{0 . 4 9}$ & 0.08 & -0.16 & 0.03 \\
\hline Seed index (SI, L/W) & 0.07 & $\mathbf{- 0 . 6 4}$ & 0.06 & -0.17 \\
\hline Seed weight (SWe, g) & 0.45 & -0.07 & 0.03 & 0.22 \\
\hline Seed color (SC) & 0.17 & 0.11 & $\mathbf{0 . 4 9}$ & $\mathbf{- 0 . 4 7}$ \\
\hline Surface (Su) & 0.27 & 0.14 & $\mathbf{0 . 5 3}$ & -0.11 \\
\hline Seed shape (SSh) & -0.11 & $\mathbf{0 . 6 3}$ & -0.06 & 0.09 \\
\hline Seed wing (SWi) & 0.04 & -0.09 & $\mathbf{- 0 . 5 5}$ & -0.14 \\
\hline
\end{tabular}

sourd diversity is useful for sponge gourd cultivar improvement in Turkey. In addition, fat and protein content of seeds should be investigated in terms of consummability.

Acknowledgments: This research was supported by TUBITAK (Project number 1160 127).

\section{References}

1. Choudhary, B. R., Pandey, S., Singh, R. (2009). Genetic diversity evaluation in satputia (Luffa hermaphrodita). Proc. Int. India Conf. Hort., p: 379-381.

2. Choudhary, B. R., Pandey, S., Singh, P. K., Singh, R. (2011). Genetic divergence in hermaphrodite ridge gourd (Luffa acutangula). Vegetable Science, 38(1): 68-72.

3. Heiser, B. C., Schilling, E. E. (1988). Phylogeny and distribution of Luffa (Cucurbitaceae). Biotropica, 20(3), 185-191.
4. Heneidak, S., Khalik, K. A. (2015). Seed coat diversity in some tribes of Cucurbitaceae: implications for taxonomy and species identification. Acta Botanica Brasilica, 29(1), 129-142.

5. Marr, K. L., Bhattarai, N. K., Xia, Y. (2005). Allazymic, morphological, and phenological diversity in cultivated Luffa acutangula from China, Laos, and Nepal, and allozyme divergence between $L$. acutangula and $L$. aegyptiaca. Economic Botany, 59(2), 154-165.

6. Mavi, K., Gündüz, K. (2016). The Collection and morphological characterization of sponge gourd (Luffa aegyptiaca Mill.) genotypes in Hatay. Project number 116 0127, TUBİTAK.

7. Prakash, K., Radhamani, J., Pandey, A., Yadav, S. (2014). A preliminary investigation of cultivated and wild species of Luffa for oil and protein contents. Plant Genetic Resources: Characterization and Utilization, 12(1), 103-111. 